\title{
Realgar transforming solution displays anticancer potential against human hepatocellular carcinoma HepG2 cells by inducing ROS
}

\author{
PENG SONG $^{1}$, PENG CHEN ${ }^{2}$, DONG WANG ${ }^{1}$, ZHENGRONG WU $^{2}$, QIYU GAO ${ }^{1}$, \\ AIXIA WANG $^{2}$, RUILAN ZHU ${ }^{2}$, YAJUN WANG ${ }^{1}$, XIN WANG $^{2}$, LONGHE ZHAO ${ }^{2}$, \\ ZIYUN DUAN $^{2}$, SHUQIAN ZHU ${ }^{2}$, PENG CUI ${ }^{2}$, YANG $\mathrm{LI}^{2}$ and HONGYU LI ${ }^{1,2}$ \\ ${ }^{1}$ Institute of Microbiology, School of Life Sciences, Lanzhou University, Lanzhou, Gansu 730000; \\ ${ }^{2}$ School of Pharmacy, Lanzhou University, Lanzhou, Gansu 730020, P.R. China
}

Received October 24, 2016; Accepted December 6, 2016

DOI: 10.3892/ijo.2016.3831

\begin{abstract}
Realgar $\left(\mathrm{As}_{4} \mathrm{~S}_{4}\right)$, as a mineral drug containing arsenic compound, has been employed in clinical therapy of cancer for its good therapeutic reputation in Chinese traditional medicine. However, large dose of realgar and long period of treatment are necessary for achieving the effective blood medicine concentration due to its low bioavailability resulted from poor solubility. In this study, we obtained realgar transforming solution (RTS) using intrinsic biotransformation in microorganism, and investigated underlying mechanisms of RTS for HepG2 cells. Our results demonstrated that an effective biotransformation of realgar method by A. ferrooxidans was established, in which realgar was biologically converted into an aqueous solution, and RTS had a strong activity inducing apoptosis and interrupting G2/M progression in HepG2 cells via upregulation of cellular ROS. Importantly, RTS inhibited the cellular antioxidant defense system leading to abundant ROS accumulation, and activated cell cycle arrest and mitochondrial pathway of apoptosis mediated by activating p53 due to cellular uncontrolled ROS. Collectively, our findings suggest that RTS is a potential candidate for therapy of human hepatocellular carcinoma.
\end{abstract}

\section{Introduction}

Aerobic organisms are continually subjected to reactive oxygen species (ROS), derivatives of $\mathrm{O}_{2}$ that are generated as

Correspondence to: Dr Hongyu Li, Institute of Microbiology, School of Life Sciences, Lanzhou University, No. 222 Tianshui Road, Lanzhou, Gansu 730000, P.R. China

E-mail: lihy@lzu.edu.cn

Abbreviations: RTS, realgar transforming solution; ROS, reactive oxygen species; ATO, arsenic trioxide; A. ferrooxidans, acidithiobacillus ferrooxidans

Key words: realgar transforming solution, HepG2 cell, reactive oxygen species, cell cycle arrest, apoptosis products or byproducts by a plethora of enzymatic reactions in life processes (1). Oxidative stress, arising from uncontrolled production of ROS beyond the neutralizing capacity of the cellular antioxidant defense system, causes cytotoxicity of chemotherapy and oxidative damage to various cellular components, such as lipids, proteins, and nucleic acids (2). Elevated oxidative stress is observed more frequently in malignant cells than in normal cells $(3,4)$. It is therefore expected that one strategy in cancer therapy is using ROS or oxidative stress causing agents or physical therapy to kill cancer cells as it seems that normal cells are more resistant to ROS than cancer cells (5).

A well deciphered and universal pathway to induce cell cycle arrest and apoptosis involves tumor suppressor protein p53 implicated upregulation of cellular ROS (1). Numerous investigations suggest that in response to cellular stresses including oxidative stress that leads to DNA damage, wild-type p53 orchestrates transcription of numerous genes and directs cells either to cell cycle arrest or apoptosis via differential activation of target genes (6,7). Under DNA damage conditions, the cytosolic P53, implicated to be one of the essential components of cell cycle checkpoints $(6,8)$, traffics to nucleus and upregulates a number of important cell cycle-modulating genes, including p21 $(9,10)$ and GADD45 $(11)$, as a transcription factor. Furthermore, recent investigations in oxidative stress, a fraction of cellular p53 traffics to mitochondria and initiates apoptosis $(12,13)$. Zhao et al found that, once in mitochondria, p53 binds to and inhibits MnSOD, playing a direct role in promoting ROS formation and eventually in apoptosismediated mitochondrial membrane depolarization (14). It is commonly accepted that p53 causes translocation of Bax to the mitochondrial membrane to create pores, which depolarize the mitochondrial membrane potential. Then, cytochrome $c$ moves into the cytosol and initiates formation of apoptosomes along with the adapter molecule Apaf-1 and other pro-caspase molecules, such as caspase-9 (15).

Arsenic trioxide $\left(\mathrm{As}_{2} \mathrm{O}_{3}\right.$; ATO), a traditional Chinese medicine with arsenic compounds, has been used in clinical therapy of human hepatocellular carcinoma as a candidate for its significant therapeutic reputation (especially extrahepatic 
metastasis). However, adverse events such as gastrointestinal upset, liver dysfunction and edema have limited wide clinical applications of arsenic trioxide (16). Realgar (another traditional Chinese medicine with arsenic compound; $\mathrm{As}_{4} \mathrm{~S}_{4}$ ), an agent for its good therapeutic reputation with low toxicity, is widely used in various clinical therapies in combination with other traditional drugs for syphilis, psoriasis, malaria, parasitic infection and cancer (17). However, a large dose of realgar and long period of treatments were necessary for achieving the effective blood medicine concentration due to its poor solubility and thus low bioavailability (18).

Traditional means of preparing realgar includes acid extraction, calcination, membrane dialysis, and mechanical milling (19). However, these technologies are often expensive and environmentally deleterious, and can be hindered by ineffective dissolution with little dissoluble arsenic (17). Bioleaching is an inexpensive and environmental technology in hydrometallurgy for the recovery of metals from their insoluble sulfide minerals by intrinsic biotransformation in microorganism. Under the inspiration of bioleaching approach, the crucial problem of poor solubility of realgar has been resolved. Acidithiobacillus ferrooxidans (A. ferrooxidans), a chemolithotrophic acidophilic bacterium utilizing both ferrous iron and elementary sulfur, is used to recover dissolvable arsenic from realgar via biotransformation (20). In our laboratory, studies on biotransformation of realgar by $A$. ferrooxidans have been carried out for more than 10 years, and it was previously found that realgar tansforming solution (RTS) significantly inhibits cell proliferation and induces apoptosis on HepG2, SMMC7721, H22 and S180 cell lines $(21,22)$, and enhances arsenic sensitivity of K562 and K562/ADM cells. Furthermore, in toxicity tests using C.elegans, RTS is less toxic and more effective arsenic in anticancer therapy than ATO (23).

As our continuing studies in developing and illustrating novel arsenic agent as potential anticancer therapeutic agents, we investigated the standard approach of preparing stable RTS according previous to research and confirming effectiveness of microorganic biotansformation by pharmacodynamics in vitro. Moreover, it was illustrated that RTS had significantly higher pharmaceutical activity in inhibiting HepG2 cells compared to ATO. Importantly, RTS inhibited the cellular antioxidant defense system and led to abundant ROS accumulation, and activated cell cycle arrest and mitochondrial pathway of apoptosis mediated by activating p53 due to uncontrolled ROS in HepG2 cells. Our study demonstrates that RTS is a potent anticancer agent in vitro, and might be a potential candidate for the therapy of human hepatocellular carcinoma.

\section{Materials and methods}

Reagents. Arsenic trioxide for injection (ATO, Yierda ${ }^{\circledR}$ ) with arsenic concentration of $10 \mathrm{mg} / \mathrm{ml}$ was purchased from Yida Medicinal Ltd. (Harbin, China). Dulbecco's modified Eagle's medium (DMEM), dimethyl sulfoxide (DMSO), Hoechst 33342, 2', 7'-dichlorfluorescein diacetate (DCFH-DA), $\mathrm{N}$-acetyl-L-cysteine (NAC) were purchased from Sigma Co. (St. Louis, MO, USA). Fetal bovine serum (FBS) was the product of Zhejiang Tianhang Biological Technology Co. (Zhejiang, China). Trypsin was purchased from
Gibco BRL (Gaithersburg, MD, USA). Propidium iodide (PI), 3-(4, 5-dimethylthiazol-2-yl)-2, 5-diphenyltetrazolium bromide (MTT), penicillin and streptomycin were obtained from Amresco (Solon, OH, USA). Dihydroethidium (DHE) were obtained from Santa Cruz Biotechnology (Santa Cruz, CA, USA). Bovine serum albumin (BSA), phenylmethylsulfonyl fluoride (PMSF) and sodium orthovanadate $\left(\mathrm{Na}_{3} \mathrm{VO}_{4}\right)$ were obtained from Beyotime (Nantong, China). Plastic tissue culture dishes were purchased from Nunc (Roskilde, Denmark). Other materials were commercial products of the highest grade available.

Preparation for RTS. Realgar was purchased from Lanzhou Antaitang Chinese Medicine Co. (Lanzhou, China), and powdered and purified by traditional methods according to the Chinese Pharmacopoeia (24), with modifications. Briefly, realgar $(500 \mathrm{~g})$ was ground into powder in water $(500 \mathrm{ml})$ to avoid oxidation of realgar, and then allowed to precipitate for $24 \mathrm{~h}$. The supernatant was carefully discarded, and the remaining realgar powder was transferred into a flat container to dry at room temperature. A. ferrooxidans BY-3 (CCTCCM203071) was isolated from the acidic mine drainage at an abandoned copper mine in Baiyin, Gansu, China. The bacteria were cultured in $9 \mathrm{~K}$ medium containing ferrous sulfate

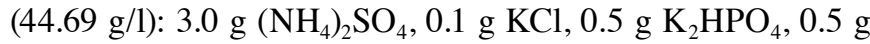
$\mathrm{MgSO}_{4} \cdot 7 \mathrm{H}_{2} \mathrm{O}, 0.01 \mathrm{~g} \mathrm{Ca}\left(\mathrm{NO}_{3}\right)_{2}$ and $44.78 \mathrm{~g} \mathrm{FeSO}_{4} \cdot 7 \mathrm{H}_{2} \mathrm{O}$ per $1,000 \mathrm{ml} \mathrm{H}_{2} \mathrm{O}, \mathrm{pH}$ 1.8. Biotransforming experiments were carried out in $250 \mathrm{ml}$ flasks, each with $100 \mathrm{ml} 1 \mathrm{~K}$ medium with ferrous sulfate $(4.469 \mathrm{~g} / \mathrm{l})$ containing $0.5 \mathrm{~g}$ of purified realgar power with an initial $\mathrm{pH}$ of 1.8. Each flask was inoculated with $A$. ferrooxidans suspension containing $1.0 \times 10^{7}$ cells $/ \mathrm{ml}$. The flasks were incubated at $150 \mathrm{rpm}$, at $30^{\circ} \mathrm{C}$ for 30 days (17). The $\mathrm{pH}$ value of realgar transforming solution (RTS) was periodically analyzed with a $\mathrm{pH}$ probe. In the end, original RTS was adjusted to $\mathrm{pH} 7.0$ with $1 \mathrm{M} \mathrm{NaOH}$ and $2 \mathrm{M}$ $\mathrm{Na}_{2}$ EDTA (ethylenediaminetetraacetic acid). RTS1, RTS2 and RTS3 were three repeating samples with similar method. Without A.ferrooxidans group (sterile), without realgar group and without $1 \mathrm{M} \mathrm{NaOH}$ and $2 \mathrm{M} \mathrm{Na}_{2}$ EDTA group (without EDTA-NaOH) were performed under similar conditions, separately. There were three repeating samples in each group. The supernatant of each group was filtered through a $0.22-\mu \mathrm{m}$ membrane to remove bacteria.

Chemical characterization of RTS. The elemental contents of RTS were analyzed using an inductively coupled plasma atomic emission spectroscope (ICP-AES, IRIS Advantage; Thermo Jarrell Ash Corp., USA). Arsenic chemical species were separated by using high performance liquid chromatography (Agilent 1100 ChemStation; Agilent Technologies, Santa Clara, CA, USA). A Dionex IonPac ${ }^{\mathrm{TM}}$ AS19 column (250 mm x ID $4.6 \mathrm{~mm}, 4 \mu \mathrm{m}$ particle size; Dionex Sciences) was used with a mobile phase containing $50 \mathrm{mM}\left(\mathrm{NH}_{4}\right)_{2} \mathrm{CO}_{3}$ (pH 9.7) and $\mathrm{H}_{2} \mathrm{O}$. The solution eluted from the column was directly introduced into an inductively coupled plasma mass spectrometer (Agilent 7500a ICP-MS; Agilent Technologies) and the As signal (m/z=75) was monitored (25).

Cell cultures and drug treatment. HepG2 cells, obtained from the Shanghai Institute of Biochemistry and Cell Biology, 
Chinese Academy of Sciences, were cultured in DMEM supplemented with $10 \%$ FBS, $2 \mathrm{mM}$ glutamine, and $100 \mathrm{U} / \mathrm{ml}$ penicillin/streptomycin and maintained in an atmosphere of $5 \% \mathrm{CO}_{2}$ at $37^{\circ} \mathrm{C}$. After reaching confluence, the cells were detached by treatment with $0.25 \%$ trypsin/ $1 \mathrm{mM}$ EDTA and replanted into different tissue culture plates for the following assays. The original realgar transforming solution (RTS) was adjusted to $\mathrm{pH} 7.0$ with $\mathrm{NaOH}$ and $\mathrm{Na}_{2}$ EDTA and used in the following assays. The various arsenic concentrations of RTS were prepared by diluting original RTS with culture media, and the arsenic concentration was indicated as concentrations of RTS.

Cytotoxicity assay. The cell viability was measured using the MTT assay. Unless otherwise noted, 10,000 cells were incubated with RTS, ATO or other agents in octuplicate in a 96-well plate for the indicated times at $37^{\circ} \mathrm{C}$ in a final volume of $100 \mu$ l. Cells treated with sterile water alone were used as controls. At the end of the treatment, $10 \mu \mathrm{l}$ MTT $(5 \mathrm{mg} / \mathrm{ml})$ was added to each well and incubated for an additional $4 \mathrm{~h}$ at $37^{\circ} \mathrm{C}$. Extraction buffer $(100 \mu \mathrm{l})(10 \% \mathrm{SDS}, 5 \%$ isobutanol, $0.1 \% \mathrm{HCl})$ was added, and the cells were incubated overnight at $37^{\circ} \mathrm{C}$. The absorbance at $570 \mathrm{~nm}$ was measured using a microplate reader (Tecan Infinite 200 PRO, Scientific Multiskan GO; Thermo Fisher Scientific, Finland).

Assessment of intracellular ROS. HepG2 cells were plated in 12 -well plates and allowed to adhere for $24 \mathrm{~h}$. The cells were treated with $0.7,1,1.5$ or $2 \mu \mathrm{g} / \mathrm{ml}$ arsenic concentrations of RTS for $12 \mathrm{~h}$. After removal of the medium, the ROS indicator DCFH-DA $(10 \mu \mathrm{M})$ or DHE $(10 \mu \mathrm{M})$ in fresh FBS-free medium was added to each well, and incubation continued for $30 \mathrm{~min}$ at $37^{\circ} \mathrm{C}$ in the dark. The cells were visualized and photographed under a Olympus inverted fluorescence microscope (IX71).

Annexin V/propidium iodide (PI) staining. HepG2 cells were treated with 1 or $1.5 \mu \mathrm{g} / \mathrm{ml}$ arsenic concentrations of RTS for 12 and $24 \mathrm{~h}$ in 12-well plates. The cells were harvested and washed with PBS. Apoptotic cells were identified by double staining with fluorescein 5-isothiocyanate (FITC)-conjugated Annexin $\mathrm{V}$ and PI according to the manufacturer's instructions (Zoman Biotech, Beijing, China). Data were obtained and analyzed using a FACSCanto flow cytometer with CellQuest software (BD Biosciences, San Jose, CA, USA).

Measurement of caspase-3 activity. HepG2 cells were treated with various arsenic concentrations of RTS for $24 \mathrm{~h}$ in $100-\mathrm{mm}$ dishes. The cells were collected, washed twice with PBS, and then lysed with RIPA buffer for $30 \mathrm{~min}$ on ice. The protein content was quantified using the Bradford procedure. A cell extract containing $50 \mu \mathrm{g}$ of total proteins was incubated with the assay mixture (50 mM HEPES, $\mathrm{pH} 7.5$, containing $2 \mathrm{mM}$ EDTA, 5\% glycerol, $10 \mathrm{mM}$ dithiothreitol, $0.1 \%$ Chaps, and $0.2 \mathrm{mM}$ Ac-DEVD-pNA) for $2 \mathrm{~h}$ at $37^{\circ} \mathrm{C}$ in a final volume of $100 \mu \mathrm{l}$. The absorbance at $405 \mathrm{~nm}$ was measured using a microplate reader.

Hoechst 33342 staining. HepG2 cells were plated in 12-well plates and were treated with various arsenic concentrations of RTS for $24 \mathrm{~h}$, followed by addition of $5 \mu \mathrm{g} / \mathrm{ml}$ Hoechst 33342 .
After incubation for $15 \mathrm{~min}$, the cells were visualized and photographed under a Olympus inverted fluorescence microscope.

Cell cycle distribution. After incubation with RTS at $1.0 \mu \mathrm{g} / \mathrm{ml}$ arsenic concentrations for $0,6,12$ and $24 \mathrm{~h}$, cells were washed twice with cold phosphate-buffered saline (PBS), and suspended in $70 \%$ ice-cold ethanol. All the samples were kept in $-20^{\circ} \mathrm{C}$ at least overnight before analysis. After washing with PBS, RNaseA ( $1 \mathrm{mg} / \mathrm{ml}$, Sigma Chemical Co.) and propidium iodine (PI, $\geq 99 \%$ purity, $50 \mu \mathrm{g} / \mathrm{ml}$, Sigma Chemical Co.) were added. Cells were filtered through a $30-\mu \mathrm{m}$ pore size nylon mesh before cell cycle analysis with a FACSCanto flow cytometer.

Analysis of MMP $(\Delta \psi)$. Cells were washed with PBS after various arsenic concentrations of RTS treatment and harvested using trypsin-EDTA solution. The cells were then made RNA free and incubated in Rhodamine 123 for 30 min to study depolarization of MMP. The fluorescence was measured using a BD FACS machine fitted with FL-1H filter.

Analysis of DNA damage activity by comet assay. HepG2 cells were plated at a density of $2 \times 10^{5}$ cells/well in 6 -well dishes. After treatment with $0.7,1.0,1.5$ and $2.0 \mu \mathrm{g} / \mathrm{ml}$ arsenic concentrations of RTS for $24 \mathrm{~h}$, cells were trypsinized and analyzed according to the manufacturer's instructions (26). Briefly, cells were embedded in agarose on a undefiled glass slide and maintained in lysis buffer $(2.5 \mathrm{M} \mathrm{NaCl}, 0.1 \mathrm{M}$ EDTA, $10 \mathrm{mM}$ Tris, $1 \%$ sodium lauryl sarcosinate, and $1 \%(\mathrm{v} / \mathrm{v})$ Triton X-100) for $1 \mathrm{~h}$ at $4^{\circ} \mathrm{C}$. Slides were then incubated with alkaline electrophoresis buffer (10 M NaOH and $200 \mathrm{mM}$ EDTA) for $60 \mathrm{~min}$ to allow the DNA to unwind. Subsequently, electrophoresis was carried out for $30 \mathrm{~min}$ at $300 \mathrm{~mA}$. Next, the slide was immersed in $70 \%$ ethanol for $5 \mathrm{~min}$, air-dried, and stained with ethidium bromide dye (Enzo Life Science). For quantification, comets on each gel were observed using an Olympus inverted fluorescence microscope.

Real-time quantitative PCR analysis. The mRNA expression of p53 in the cells was quantitatively determined at $0,3,6$ and $12 \mathrm{~h}$ after treatment. Total RNA was extracted from the cells using RNAiso kit (Takara Biotechnology). Single stranded cDNA was synthesized from $1 \mu \mathrm{g}$ total RNA with Primescrip ${ }^{\mathrm{TM}} \mathrm{RT}$ reagent kit (Takara Biotechnology). Real-time PCR was performed using $2 \mu \mathrm{l}$ of cDNA product in a $20-\mu 1$ reaction volume with 7300 Real-time PCR system (Applied Biosystems, Singapore). SYBR $^{\circledR}$ Premix Ex Taq ${ }^{\mathrm{TM}}$ II (Takara Biotechnology) and specific primers were used in each PCR reaction. All real-time PCR reactions were performed in triplicate for each sample, and the results after calibration with GAPDH expression were calculated using the $2^{-\Delta \Delta \mathrm{Ct}}$ method $\left(\Delta \Delta \mathrm{Ct}=\mathrm{Ct}_{\text {sample }}-\mathrm{Ct}_{\mathrm{GAPDH}}\right)$. The primer sequences for detecting human p53 cDNA were 5'-CCT CAGCATCTTATCCGAGTGG-3' (forward) and 5'-TGGATG GTGGTACAGTCAGAGC-3' (reverse). Primer sequences for glyceraldehyde-3-phosphate dehydrogenase (GAPDH) were 5'-AGAAGGCTGGGGCTCATTTG-3' (forward) and 5'-AGG GGCCATCCACAGTCTTC-3' (reverse).

Western blotting quantification of protein expression. The protein expression of the cells was quantitatively determined 
by western blotting at 0,12 and $24 \mathrm{~h}$ after treatment. Briefly, cells were washed twice with ice-cold PBS, and the proteins in each dish were extracted with $200 \mu 1$ lysis buffer containing $2 \mathrm{mM}$ sodium orthovanadate and $10 \mathrm{mM} \mathrm{NaF}$ as phosphatase inhibitors and a proteinase inhibitor cocktail. The lysates were centrifuged at $12,000 \mathrm{~g}$ for $15 \mathrm{~min}$ at $4^{\circ} \mathrm{C}$. The supernatants were collected and total protein content was determined using the BCA Protein assay kit. Cytosolic and mitochondrial extracts were performed according to the manufacturer's instructions of Mitochondria Extraction kit (Solarbio Bioscience and Technology, Shanghai, China). The sample proteins were denatured for $5 \mathrm{~min}$ at $100^{\circ} \mathrm{C}$ with a loading buffer, followed by being subjected to $12 \%$ SDS-PAGE electrophoresis and then electrotransferred onto a PVDF membrane $(0.45 \mu \mathrm{m})$. After being blocked with $5 \%$ skim milk for $2 \mathrm{~h}$ at room temperature and washed with TBS, the membranes were incubated overnight at $4^{\circ} \mathrm{C}$ with primary antibodies. After washing with TBS, the membranes were incubated for $2 \mathrm{~h}$ at $37^{\circ} \mathrm{C}$ in TBS containing $5 \%(\mathrm{w} / \mathrm{v}) \mathrm{BSA}$ and horseradish peroxidase-conjugated secondary antibodies. The signal was detected using an enhanced chemiluminescence kit (Solarbio Bioscience and Technology) from GE Healthcare.

Statistical analysis. Statistical analyses were carried out with the SPSS 16.0 software (SPSS Inc., Chicago, IL, USA). The significance levels were determined by one-way ANOVA. Multiple comparisons were carried using the Tukey method. A value of $\mathrm{P}<0.05$ was taken as a significant difference. The data are shown as means \pm standard deviation (SD).

\section{Results}

Chemical characterization and cytotoxicity of RTS. In this study, we attempted to recover arsenic from realgar based on bioleaching according to a well established assay (22). The changes in bacterial population and $\mathrm{pH}$ value of prepared RTS over time are shown in Fig. 1A. During the first 20 days of the experiment, the free bacterial population increases continually, and then slightly falls in the last 10 days, along with the resulting decrease of $\mathrm{pH}$ value during the first 25 days and a slight increase in the last 5 days. Fig. 1B shows the changes in arsenic concentration of RTS over time. The arsenic concentration gradually increase within 30 days in the presence of A.ferrooxidans BY-3, while for the group at the same conditions without bacteria, there was little dissolved arsenic detected.

As an extract from biotransforming of mineral drug (realgar) by A.ferrooxidans, the main components of RTS must be inorganic ions. Therefore, total elemental analysis was done by ICP-AES (Fig. 1C). K, Ca, Mg, Mn, Fe and As were confirmed to be contained in RTS, while others were at levels lower than the detection limit and therefore not shown. Arsenic chemical species were analysized using HPLC-ICP-MS monitor. It shows that the main arsenic species contained in RTS was inorganic trivalent arsenic.

The $\mathrm{pH}$ value of original RTS was $<1.7$, and it contained various inorganic ions leading to poor stability for standing storage, therefore, the original RTS was adjusted with $\mathrm{NaOH}$ and $\mathrm{Na}_{2}$ EDTA. To determine whether $\mathrm{NaOH}$ and $\mathrm{Na}_{2}$ EDTA contributed to the intrinsic cytotoxicity of original RTS, we compared their cytotoxicity and the result indicated that the cell viablility of HepG2 cells was significantly inhibited by either RTS or RTS without EDTA-NaOH in a concentrationdependent manner, and there was no significant difference between them (Fig. 1D). In groups with the absence of A.ferrooxidans or realgar, there was no obvious inhibition on cell viability at the different supernatant contents (Fig. 1D). This further confirmed that the biological activity of A. ferrooxidans is required for the biotransformation of realgar.

Stable cytotoxicity of RTSs toward HepG2 cells. To determine the stable RTS cytotoxicity with preparation in triplicate, HepG2 cells were treated with different concentrations of RTSs for 12 and $24 \mathrm{~h}$, respectively, in our study. The MTT results demonstrated concentration- and time-dependent cytotoxicity after exposure to RTS (Fig. 1E). We found that RTS at various dosages displayed potent cytotoxicity toward HepG2 cells following both 12 - and 24-h treatments; and cytotoxicity of RTS with 12-h treatment is higher than 24-h treatment. In addition, RTS used in our experiment displayed stable cytotoxicity from triplicate independent preparation experiments (RTS1, RTS2 and RTS3). Arsenic trioxide (ATO), which is commercially available in anticancer therapy, was also used as control in this study. Results indicated that the cytotoxicity of RTS was significantly higher than that of ATO with the same concentration of arsenic upon 12 or 24-h treatments (Fig. 1F).

Induction of apoptosis in HepG2 cells by activation of p53 signaling pathway. We investigated whether RTS kills HepG2 cells predominantly through induction of apoptosis. Flow cytometry analysis was conducted using Annexin V-FITC/ PI staining to investigate the mode of cell death induced by RTS. We observed that RTS triggered apoptotic cell death dose- and time-dependently (Fig. 2A). The cells treated with $1.5 \mu \mathrm{g} / \mathrm{ml}$ RTS for $24 \mathrm{~h}$ showed $>60 \%$ apoptotic cells stained with Annexin V-FITC and propidium iodide. This finding suggests that apoptosis is one of the mechanisms involved in the antitumor activity of RTS. To further confirm the induction of apoptosis by RTS, Hoechst 33342 staining was employed. Untreated cells had round and homogeneously stained nuclei, while cells treated with RTS from 0.7 to $2 \mu \mathrm{g} / \mathrm{ml}$ for $24 \mathrm{~h}$ showed marked DNA condensation and apoptotic bodies dose-dependently (Fig. 2B), which are considered important characteristics of apoptosis.

To investigate the RTS mechanisms underlying the induction of apoptosis in HepG2 cells, we tested whether RTS could modulate the levels of key apoptotic and signaling proteins. Western blotting was used to examine the levels of key apoptotic and signaling proteins after treatment with RTS for 0,12 and $24 \mathrm{~h}$, respectively (Fig. 2C). Our results showed that protein expression levels increase in Bax and decrease in Bcl-2. Moreover, a decrease of pro-caspase- 3 and survive levels, and an increase of the cleaved-caspase-3 and p53 levels were observed. Moreover, real-time quantitative PCR was used to investigate the mRNA expression of p53 in the HepG2 cells, which was quantitatively determined at 0, 3, 6 and $12 \mathrm{~h}$ after treatment with RTS. We observed that mRNA expression levels of P53 with a significant increase in a timedependent manner (Fig. 2D). We further measured the activity of caspase-3 upon RTS treatment for $24 \mathrm{~h}$. Treatment with 
A

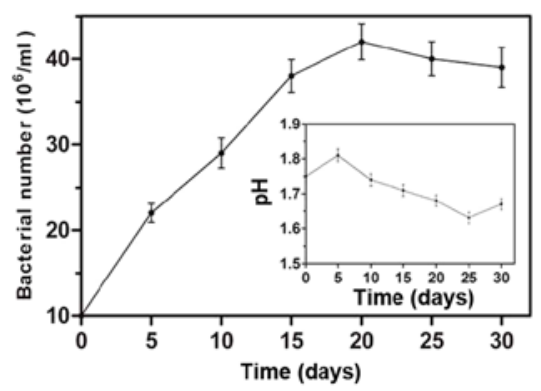

D

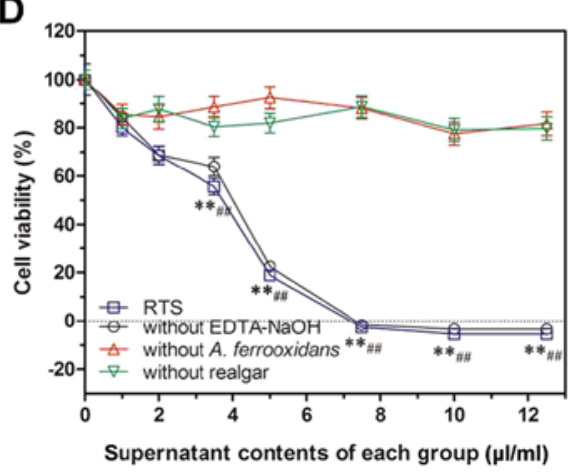

B

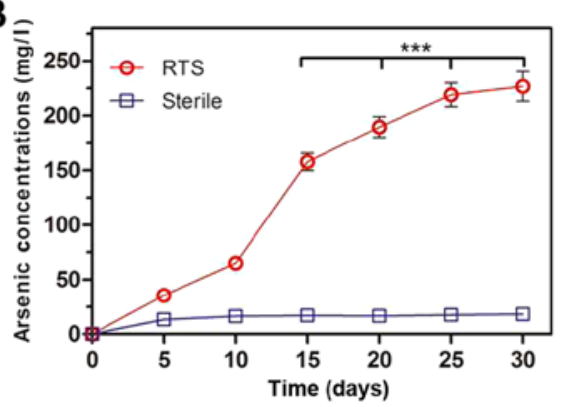

E

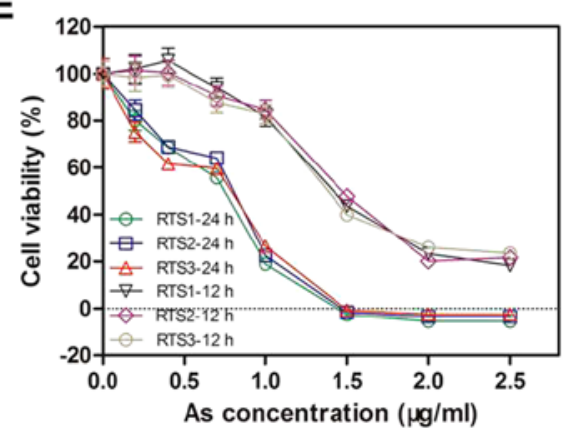

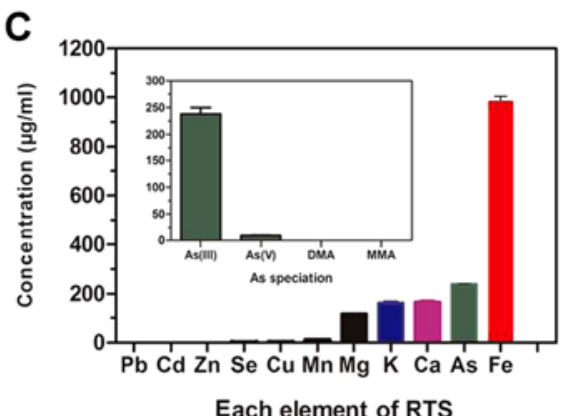

F

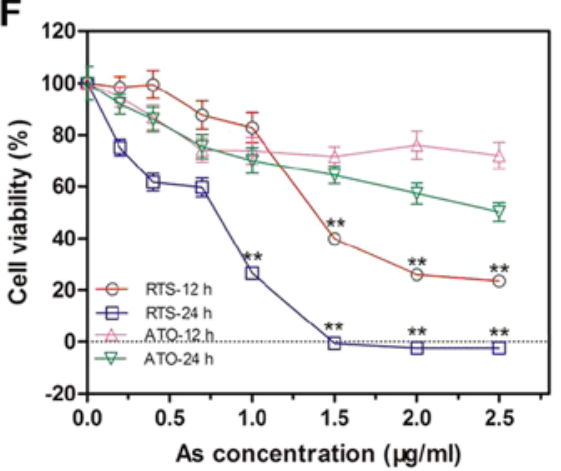

Figure 1. (A) The dynamic changes in bacterial population (outer graph) and $\mathrm{pH}$ value (inner graph) of preparing RTS over time (n=3 for each time-point). (B) The dynamic changes in arsenic concentration of RTS and sterile medium with equal realgar over time ( $\mathrm{n}=3$ for each time-point in each group, ${ }^{* * *} \mathrm{P}<0.005$ vs sterile group). (C) The element contents of RTS (outer graph) and the assay of arsenic chemical species including arsenite [As (III)], arsenate [As (V)], monomethyl arsonic acid (MMA) and dimethylarsinic acid (DMA) at 30 days (n=3 for each group). (D) Cytotoxicity of RTS group, without A.ferrooxidans group, without EDTA-NaOH group, without realgar group toward HepG2 cells. The cells $\left(1 \times 10^{4}\right)$ were treated with various agents for 24 h, and the viability was determined by the MTT method ( $\mathrm{n}=8$ for each concentration in each group, ${ }^{* *} \mathrm{P}<0.01$ vs without $A$. ferrooxidans group, ${ }^{\#} \mathrm{P}<0.01$ vs without realgar group). (E) Time-dependent stable cytotoxicity of RTS with preparation in triplicate (RTS1, RTS2 and RTS3) to HepG2 cells. The cells (1x10 ${ }^{4}$ ) were treated with the indicated arsenic concentrations of RTS for 12 and $24 \mathrm{~h}$, and the viability was determined by the MTT method (n=8 for each concentration in each group). (F) Time-dependent cytotoxicity of RTS and ATO to HepG2 cells. The cells $\left(1 \times 10^{4}\right)$ were treated with the indicated arsenic concentrations of RTS and ATO for 12 and $24 \mathrm{~h}$, and the viability was determined by the MTT method ( $\mathrm{n}=8$ for each concentration in each group, ${ }^{* *} \mathrm{P}<0.01$ vs ATO group in corresponding time).

various arsenic concentrations of RTS significantly increased the caspase- 3 activity in a dose-dependent manner (Fig. 2E).

Induction of oxidative stress and DNA damage in HepG2 cells by RTS. We investigated whether RTS treatment could inhibit the cellular antioxidant defense system which led to abundant ROS accumulating. We observed that intracellular ROS level detected by DCFH-DA staining was strongly elevated upon treatment with RTS in a time-dependent manner (Fig. 3A). We further employed the dye DHE. It showed that intracellular ROS level detected by DHE staining was elevated after treatment with RTS in a time-dependent manner (Fig. 3B).

Comet assay, one of the standard methods for assessing DNA damage or apoptosis, was used in order to evaluate the oxidative base damage in DNA after RTS exposure. The representative picture of comet images for HepG2 cells treated with RTS for $24 \mathrm{~h}$ is shown in Fig. 3C. We observed that RTS resulted in increase in tail moment, tail length, and the percentage of DNA fragmentation. Moreover, the comet head is reduced in size and fluorescence intensity after treatment with RTS. Our result indicated that the severe DNA damage was induced by the RTS in a dose-dependent manner.

Alleviation of cytotoxicity by NAC. To demonstrate whether the cytotoxic effect of RTS was closely related to increased
ROS levels, the effect of RTS on cell viability after pretreatment with NAC, a well-known antioxidant, was measured by the MTT assay. Our result indicated that pretreatment of HepG2 cells with NAC could significantly protect against RTS-induced cytotoxicity, and RTS induced cytotoxicity was completely blocked by NAC at higher concentrations (Fig. 3D). In addition, Hoechst 33342 staining assay also showed that RTS-induced apoptosis in HepG2 cells was resumed by NAC (Fig. 3E), which is consistent with the cytotoxicity assay. These results indicated that apoptosis of HepG2 cells might be a consequence of increased ROS levels induced by RTS. To further confirm the increased ROS levels induced by RTS lead to cytotoxic and DNA damage potential on cancer cells, the cells were stained by DHE (Fig. 3G) and fluorescent dyes DCFH-DA (Fig. 3H) after treatment with RTS and NAC for $24 \mathrm{~h}$, in addition, comet assay was used according to the described treatment (Fig. $3 \mathrm{H}$ ). We observed that pretreatment of the cells with the antioxidant NAC remarkably alleviates the ROS level and DNA damage induced by RTS.

Depolarization of the mitochondrial outer membrane. Depolarization of the mitochondrial outer membrane induced by ROS causes the loss of mitochondrial membrane potential $(\Delta \psi)$, which is catastrophic for cells and leads to the release of cytochrome $c$ into the cytosol. The $\Delta \psi$ was evaluated in 
A

$12 \mathrm{~h}$
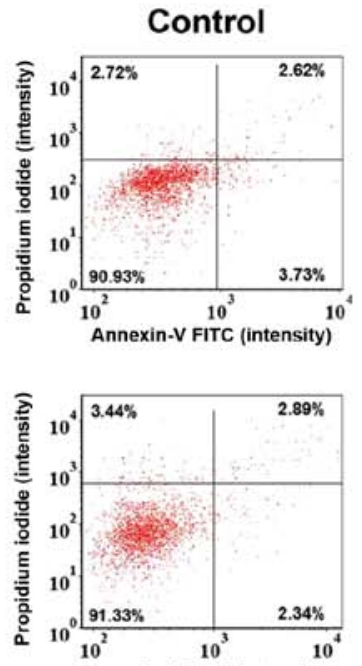

Annexin-V FITC (intensity)
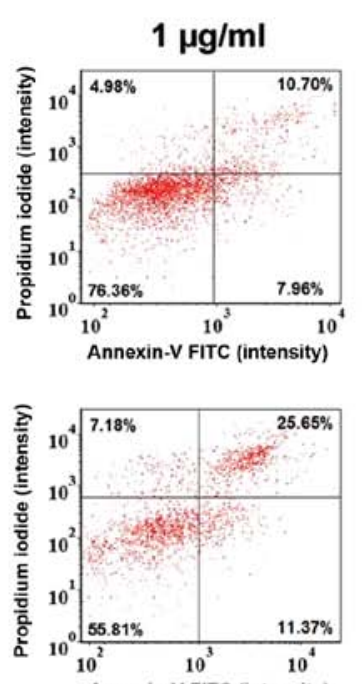

Annexin-V FITC (intensity)

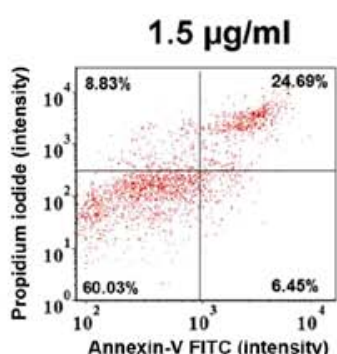

Annexin-V FITC (intensity)

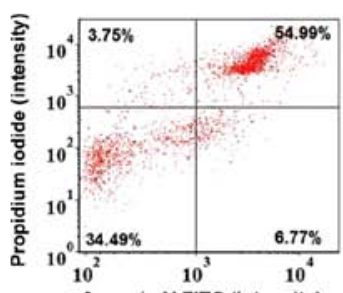

Annexin-V FITC (intensity)

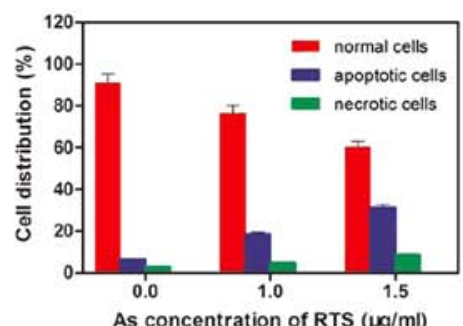

As concentration of RTS $(\mu \mathrm{g} / \mathrm{ml})$

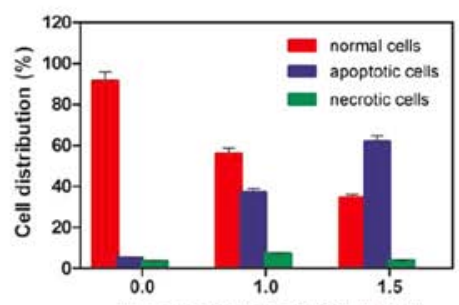

As concentration of RTS $(\mu \mathrm{g} / \mathrm{ml})$

B

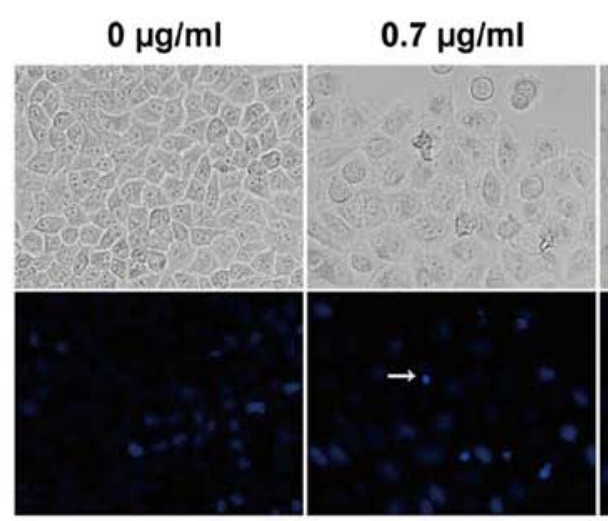

$1.0 \mu \mathrm{g} / \mathrm{ml}$

$1.5 \mu \mathrm{g} / \mathrm{ml}$

$2.0 \mu \mathrm{g} / \mathrm{ml}$

C

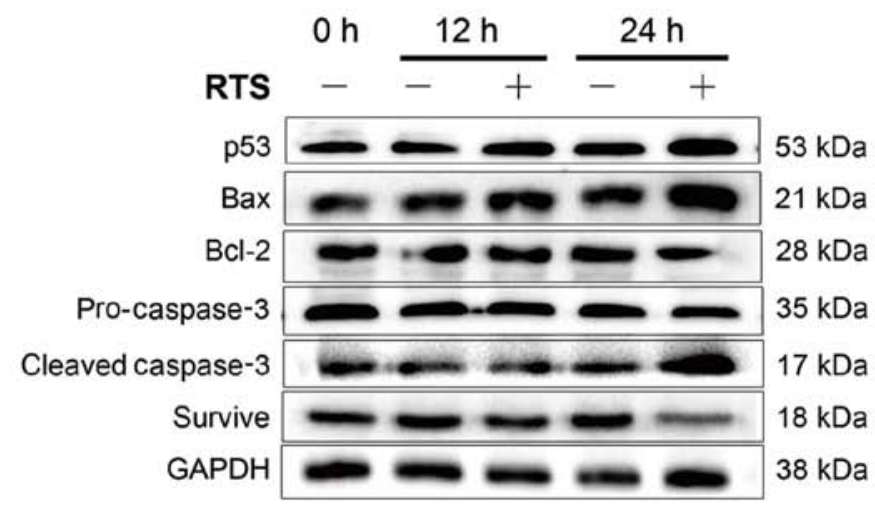

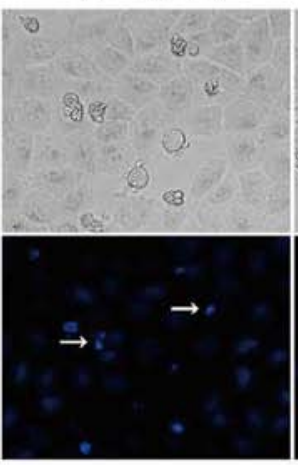

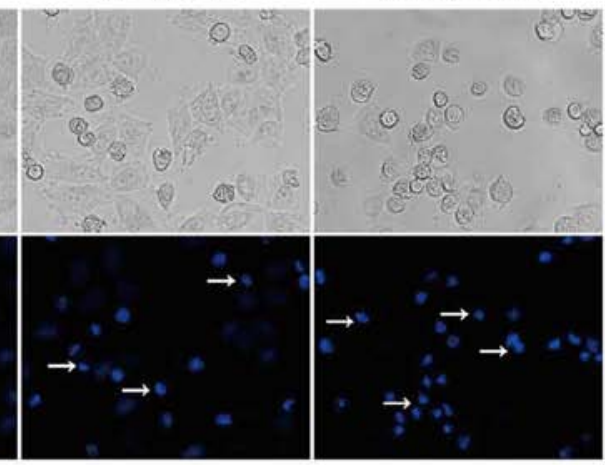

D

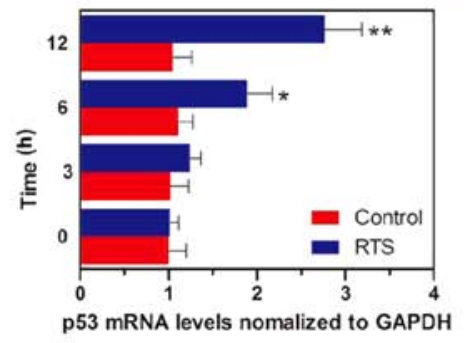

$\mathbf{E}$

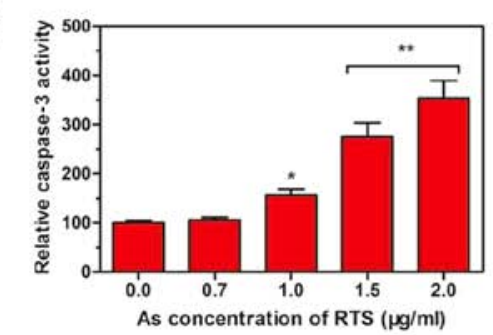

Figure 2. (A) Analysis of apoptosis by Annexin V/PI double-staining assay. HepG2 cells were treated with various arsenic concentrations of RTS for 12 or $24 \mathrm{~h}$, and the representative FACS analysis scattergrams of Annexin V-FITC/PI staining are shown on the left ( $\mathrm{n}=3$ for each concentration in each time-point). The cells show four different cell populations marked as follows: double-negative (unstained) cells showing the live cell population (lower left, Q3), Annexin V-positive- and PI-negative-stained cells showing early apoptosis (lower right, Q4), Annexin V/PI-double-stained cells showing late apoptosis (upper right, Q2), and finally PI-positive- and Annexin V-negative-stained cells showing dead cells (upper left, Q1). The quantification of dead cells (Q1) and apoptotic cells (Q2 and Q4) is illustrated on the right. (B) Analysis of apoptosis by nuclear condensation. The Hoechst 33342 staining showed typical apoptotic morphology changes (indicated by arrows, x200) after RTS treatment. Cells were incubated with various arsenic concentrations of RTS for $24 \mathrm{~h}$ followed by Hoechst 33342 staining. Phase contrast (top) and fluorescence (bottom) images were acquired by fluorescence microscopy (Olympus IX71). (C) Effect of RTS on expressions of key cell-apoptotic regulators mediated by 533 in HepG2 cells. After the cells were treated with RTS (1.5 $\mu \mathrm{g} / \mathrm{ml}$ arsenic concentrations) for 0,12 and $24 \mathrm{~h}$, they were harvested, and different cell extracts were prepared as described in Materials and methods. The protein expression was analyzed by western blotting, and GAPDH was used as a loading control. (D) Induction of p53 genes in HepG2 cells by RTS. The cells were treated with RTS (1.5 $\mu \mathrm{g} / \mathrm{ml}$ arsenic concentrations) for $0,3,6$ and $12 \mathrm{~h}$, and the mRNA level of p53 genes was analyzed and normalized using GAPDH as an internal standard by qRT-PCR as described in Materials and methods ( $\mathrm{n}=3$ for each time-point in each group, ${ }^{*} \mathrm{P}<0.05$ vs control group, ${ }^{* *} \mathrm{P}<0.01$ vs control group). (E) Activation of caspase-3 by RTS in HepG2 cells. The cells were incubated with the indicated arsenic concentrations of RTS for $24 \mathrm{~h}$ and the caspase- 3 activity in the cell extracts was determined by a colorimetric assay ( $\mathrm{n}=3$ for each group, ${ }^{*} \mathrm{P}<0.05$ vs control group, ${ }^{* *} \mathrm{P}<0.01$ vs control group). 


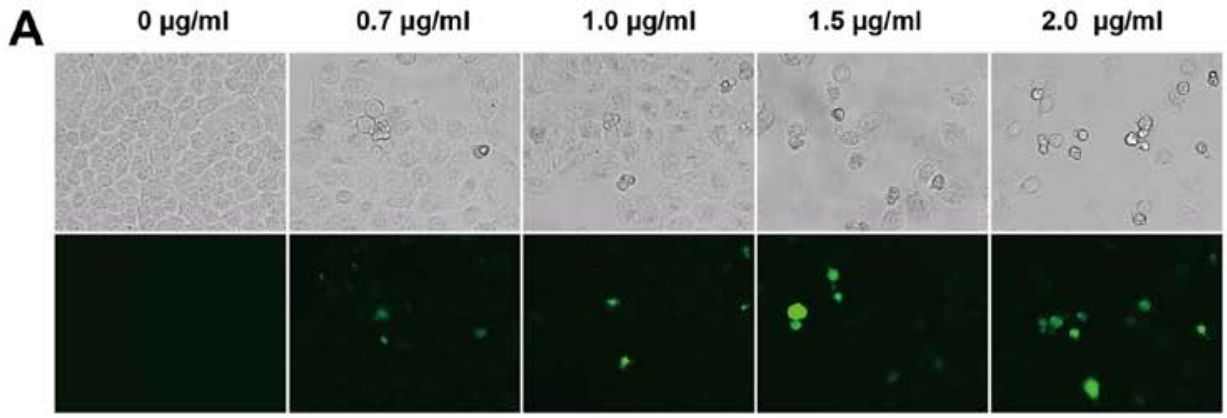

B
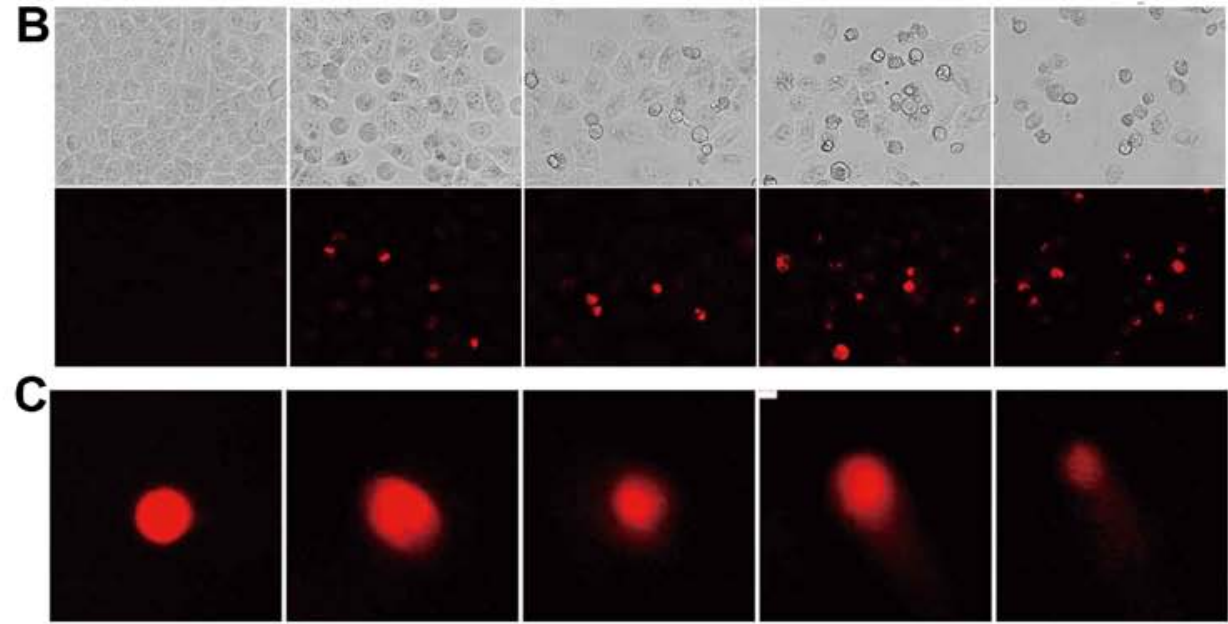

\section{D}

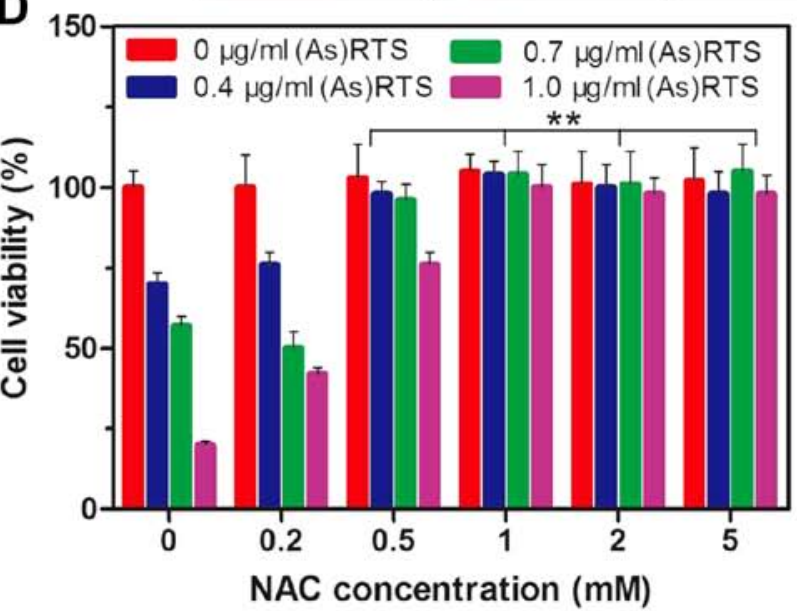

$\mathbf{E}$

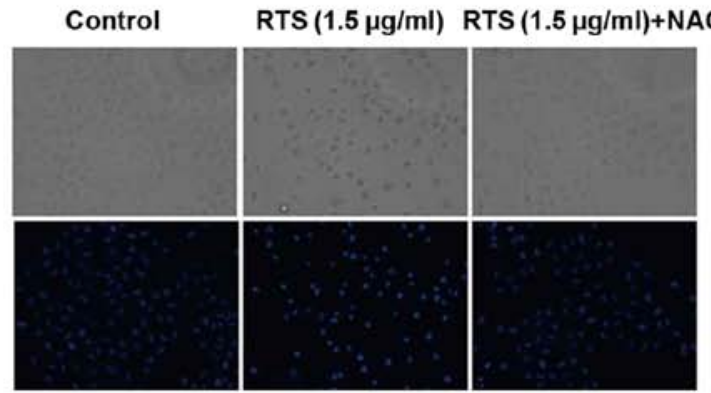

$F$
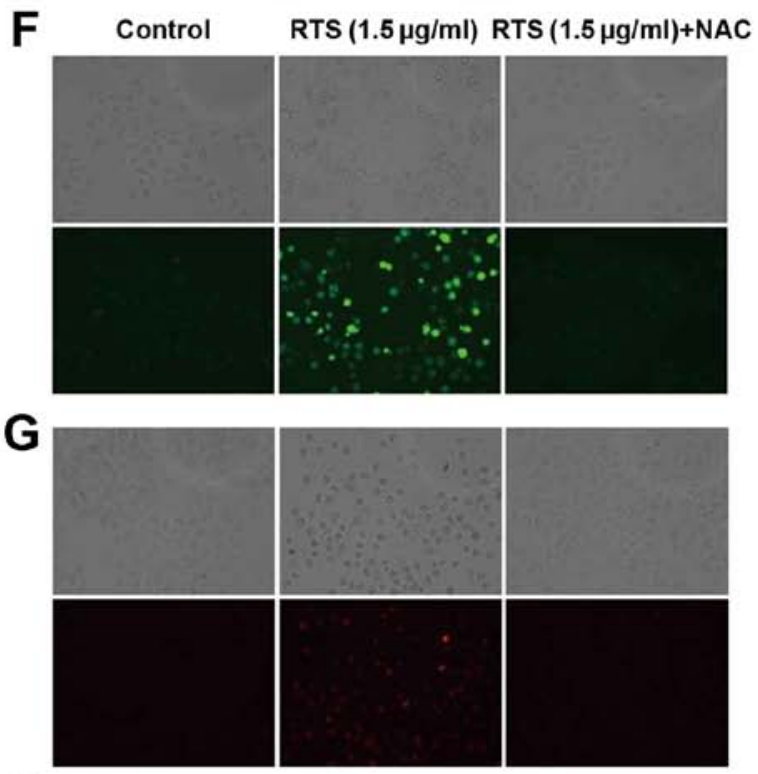

$\mathbf{H}$
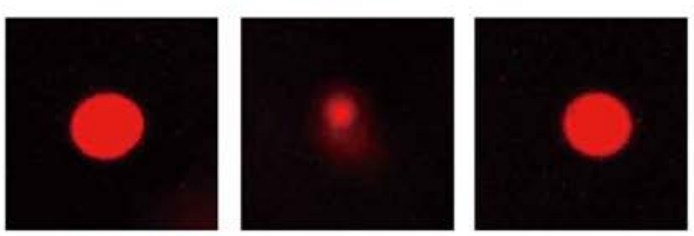

Figure 3. (A and B) Accumulation of ROS in the cells by (A) DCFH-DA staining and (B) DHE staining. HepG2 cells were treated with various arsenic concentrations of RTS for $12 \mathrm{~h}$ followed by incubation with the fluorescent probe DCFH-DA (10 $\mu \mathrm{M})$ or DHE (10 $\mu \mathrm{M})$ for $30 \mathrm{~min}$. Phase contrast (top) and fluorescence (bottom) images were acquired by fluorescence microscopy (Olympus IX71). Results shown are representative of three independent experiments (x200). (C) Comet assay for measuring DNA damage in HepG2 cells. After the cells were treated with various arsenic concentrations of RTS for 24 h, they were harvested, and different cells were prepared as described in Materials and methods. Results shown are representative of three independent experiments (x400). (D) Alleviation of cytotoxicity by NAC. HepG2 cells $\left(1 \times 10^{4}\right)$ were seeded on 96 -well plates and allowed to attach for 24 h. Then the cells were incubated with the indicated concentrations of NAC and RTS $(0,0.4,0.7$ and $1.0 \mu \mathrm{g} / \mathrm{ml}$ arsenic concentrations) for $24 \mathrm{~h}$. Cell viability was determined by the MTT assay ( $\mathrm{n}=3$ for each arsenic concentration in each group, ${ }^{* *} \mathrm{P}<0.01$ vs control group in corresponding arsenic concentration). (E) Alleviation of nuclear condensation by NAC. HepG2 cells were incubated with $1.5 \mu \mathrm{g} / \mathrm{ml}$ arsenic concentrations of RTS and 5 mM NAC for $24 \mathrm{~h}$ followed by Hoechst 33342 staining (x100). (F and G) Alleviation of ROS by NAC. HepG2 cells were incubated with $1.5 \mu \mathrm{g} / \mathrm{ml}$ arsenic concentrations of RTS and 5 mM NAC for $24 \mathrm{~h}$ followed by (F) DCFH-DA staining and (G) DHE staining (x100). (H) Alleviation of DNA damage by NAC. HepG2 cells were incubated with $1.5 \mu$ g/ml arsenic concentrations of RTS and $5 \mathrm{mM}$ NAC for $24 \mathrm{~h}$ followed by comet assay (x400). 
A
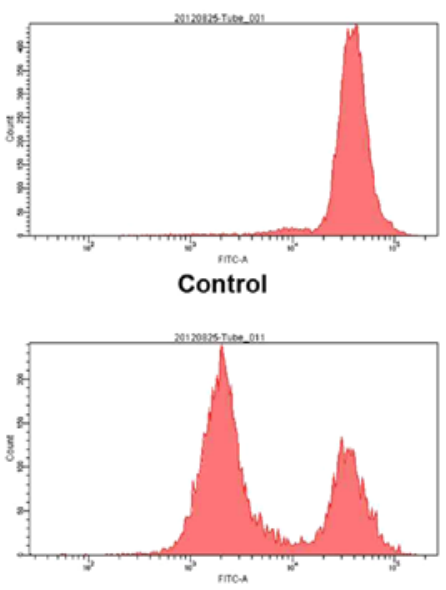

$1.5 \mu \mathrm{g} / \mathrm{ml}$

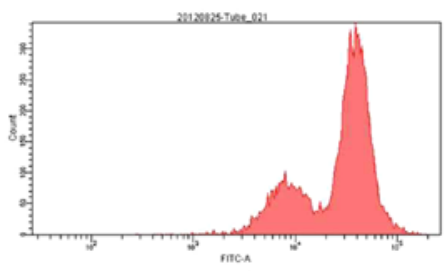

$0.7 \mu \mathrm{g} / \mathrm{ml}$

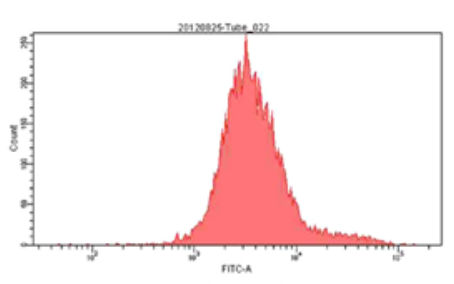

$2.0 \mu \mathrm{g} / \mathrm{ml}$

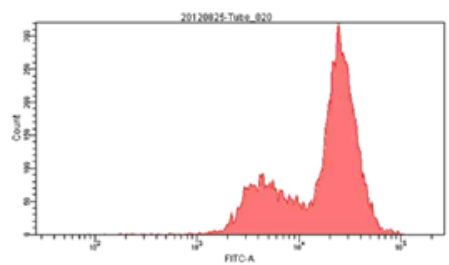

$1.0 \mu \mathrm{g} / \mathrm{ml}$

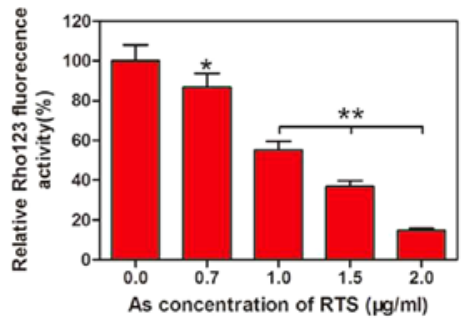

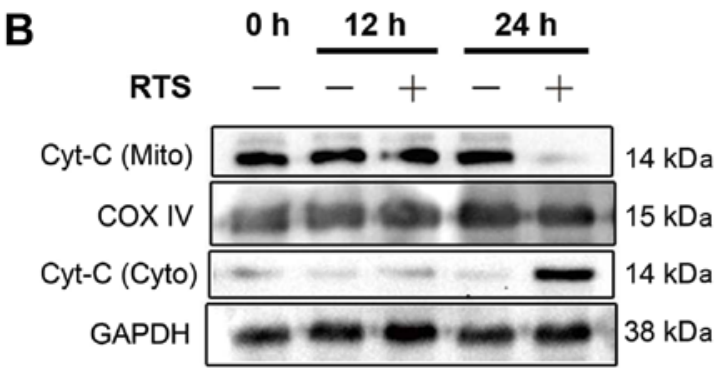

Figure 4. (A) Analysis of MMP $(\Delta \psi)$ by Rhodamine 123 staining. HepG2 cells were incubated with various arsenic concentrations of RTS for $12 \mathrm{~h}$, they were harvested, and different cells were prepared as described in Materials and methods. The relative Rhodamine 123 fluorescence activity $(\%)$ indicates MMP $(\Delta \psi)$. The representative MMP $(\Delta \psi)$ analysis are shown ( $=3$ for each concentration, ${ }^{* *} \mathrm{P}<0.01$ vs control group). (B) Effect of RTS on release of cytochrome $c$ from the mitochondria and its accumulation in the cytosol. After HepG2 cells were treated with RTS $(1.5 \mu \mathrm{g} / \mathrm{ml}$ arsenic concentrations) for 0,12 and $24 \mathrm{~h}$, they were harvested, and different cell extracts were prepared as described in Materials and methods. The protein expression was analyzed by western blotting. COX IV and GAPDH were, respectively, used as loading control in mitochondria and cytosol.
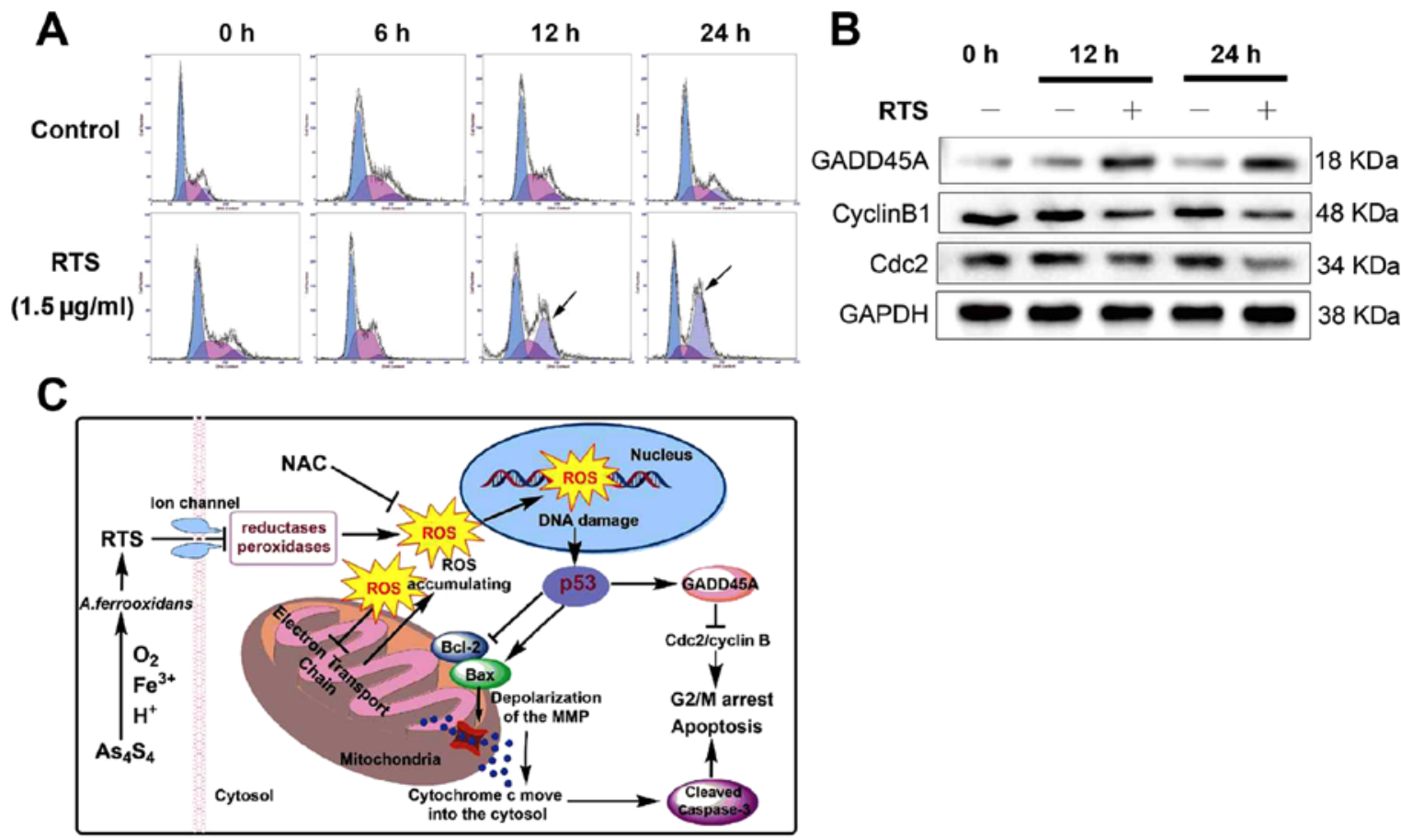

Figure 5. (A) Effect of RTS on cell cycle arrest. After HepG2 cells were treated with RTS (1.5 $\mu \mathrm{g} / \mathrm{ml}$ arsenic concentrations) for $0,6,12$ and $24 \mathrm{~h}$, they were harvested, and different cells were prepared as described in Materials and methods. Results shown are representative of three independent experiments, and the G2/M arrest is indicated by arrows. (B) Effect of RTS on expressions of key cell cycle regulators in HepG2 cells. After the cells were treated with RTS $(1.5 \mu \mathrm{g} / \mathrm{ml}$ arsenic concentrations) for 0,12 and $24 \mathrm{~h}$, they were harvested, and different cell extracts were prepared as described in Materials and methods. The protein expression was analyzed by western blotting, and GAPDH was used as a loading control. (C) A novel anticancer mode of RTS in HepG2 cells. 
HepG2 cell using the fluorescent dye Rhodamine 123 staining. Fig. 4A displays $\Delta \psi$ in HepG2 cells treated with RTS for $24 \mathrm{~h}$ at various arsenic concentrations, and significant decrease of $\Delta \psi$ was observed in cancer cells exposed to RTS ranging from 1.0 to $2.0 \mu \mathrm{g} / \mathrm{ml}$ arsenic. We further investigated whether RTS could induce release of cytochrome $c$ from mitochondria and its accumulation in cytosol by using western blotting. The result indicated that RTS resulted in the release of cytochrome $c$ from mitochondria into cytosol at $24 \mathrm{~h}$, compared with the non-induced condition (Fig. 4B), supporting the notion that the induction of apoptosis by RTS treatment involves the dysfunction of mitochondrial signaling pathway.

Induction of cell cycle arrest in HepG2 cells by cell cycle regulators. To further detect the cell cycle arrest effect of RTS on HepG2 cells, the cell cycle progression after treatment with RTS for $0,6,12$ and $24 \mathrm{~h}$, respectively, was quantified. It can be seen in Fig. 5A that HepG2 cells exposed to RTS with $1.5 \mu \mathrm{g} / \mathrm{ml}$ arsenic concentrations displayed marked accumulation in the $\mathrm{G} 2 / \mathrm{M}$ phase in a time-dependent manner. In addition, the regulatory molecules GADD45A, cyclin B1 and $\mathrm{Cdc} 2$ expression was analyzed. When cancer cells were incubated for 12 or $24 \mathrm{~h}$ with $1.0 \mu \mathrm{g} / \mathrm{ml}$ RTS, a dose-dependent decrease in the cyclin $\mathrm{B} 1$ and $\mathrm{Cdc} 2$ protein levels was seen, and an increase in the GADD45A protein level was observed (Fig. 5B). Taken together with western blotting data from cell cycle regulatory molecules, these findings suggest that the cell cycle arrest at G2/M phase by RTS is mediated via controlling the $\mathrm{G} 2$ checkpoint and modulating the levels and activities of cell cycle regulatory molecules, which may depend on the p53-associated mechanism.

\section{Discussion}

Arsenic, the 20th most abundant element in the earth's crust has become a worldwide health concern due to its toxicity and carcinogenicity $(27,28)$. There are 3 inorganic arsenic forms, namely, red arsenic $\left(\mathrm{As}_{4} \mathrm{~S}_{4}\right.$, also known as realgar), yellow arsenic $\left(\mathrm{As}_{2} \mathrm{~S}_{3}\right.$, also known as orpiment), and white arsenic (arsenic trioxide, ATO; $\mathrm{As}_{2} \mathrm{O}_{3}$ ) (29). Arsenic compounds, including arsenic sulfide $\left(\mathrm{As}_{4} \mathrm{~S}_{4}\right)$ and arsenic trioxide $\left(\mathrm{As}_{2} \mathrm{O}_{3}\right)$, were used to treat leukemia in the mid-19th century (30). Also, over the last decades these compounds have been used with great success in the treatment of human hepatocellular carcinoma (16). While their current clinical disadvantages prompt us to explore other arsenic derivatives with better anticancer efficacy but fewer side effects.

Bioleaching approach, a long-standing technology of recovery of heavy metals by applying microorganisms from their insoluble sulfide minerals, has recently been applied to the field of pharmaceuticals. Interestingly, the A.ferrooxidans act as an oxidizer for ferrous ion which is produced in the dissolution of $\mathrm{As}_{4} \mathrm{~S}_{4}$ (realgar) and succeeded in recovery of arsenic (17). However, arsenic is toxic to bacteria. Therefore, we recovered arsenic from realgar by taking advantage of an arsenic-resistant strain of indigenous A. ferrooxidans BY-3 (Fig. 1B), and confirmed the steady antitumor activities of RTS in vitro required for the biotransformation of realgar (Fig. 1D and E), the reactions in the bioleaching of realgar may have occurred as described in equations 1-3 (17). First, ferrous sulfate in the culture is oxidized to ferric sulfate by A. ferrooxidans. Then, realgar is oxidized by ferric ions to release arsenic and form sulfur. Finally, sulfur is oxidized to sulfuric acid by A.ferrooxidans, which can remove the diffusion barrier covering the surface of realgar and promote ferric iron to further reaction. Results show that the main arsenic species contained in RTS were inorganic trivalent arsenic, in agreement with previous research.

$$
\begin{aligned}
& 4 \mathrm{Fe}^{2+}+\mathrm{O}_{2}+4 \mathrm{H}^{+} \stackrel{\text { Acidithiobacillus ferrooxidans }}{\longrightarrow} 4 \mathrm{Fe}^{3+}+2 \mathrm{H}_{2} \mathrm{O} \\
& \mathrm{As}_{4} \mathrm{~S}_{4}+2 \mathrm{Fe}^{3+} \longrightarrow 4 \mathrm{As}^{3+}+2 \mathrm{Fe}^{2+}+4 \mathrm{~S}^{0} \\
& 4 \mathrm{~S}^{0}+4 \mathrm{H}_{2} \mathrm{O}+6 \mathrm{O}_{2} \stackrel{\text { Acidithiobacillus ferrooxidans }}{\longrightarrow} 4 \mathrm{SO}_{4}{ }^{2-}+8 \mathrm{H}^{+}
\end{aligned}
$$

What is significant in our investigation is that the cytotoxicity of RTS was significantly higher than that of ATO at the same concentration of arsenic (Fig. 1F). The chemical characterization of RTS demonstrated that $\mathrm{K}, \mathrm{Ca}, \mathrm{Mg}, \mathrm{Mn}$ and Fe were contained in RTS. These results suggest that the higher cytotoxicity for HepG2 cells is attributed to arsenic cooperating with other inorganic ions in RTS, especially $\mathrm{Fe}$ with the highest concentration. Previous studies have clearly demonstrated that $\mathrm{Fe}$ can interfere with the mitochondrial electron transport chain (METC) in cancer cells and induce the formation of ROS in mitochondria, which further affects the production of ATP, mitochondrial membrane potential, and microdistribution of calcium, and induces cell apoptosis (31). Therefore, it implies that RTS may be a promising anticancer drug candidate with high activity and low concentration arsenic cooperating with Fe.

The cellular toxicity of arsenic is due to its high affinity for the sulfhydryl groups of biomolecules such as glutathione, lipoic acid and the cysteinyl residues of many proteins and enzymes (27). It was recently reported that the formation of As-sulfur bonds results in various cellular toxicity by inhibiting the activities of enzymes such as glutathione reductase, glutathione peroxidases, thioredoxin reductase, and thioredoxin peroxidase $(32,33)$. Arsenic exposure leads to larger production of ROS due to the enzymes regulating cellular redox status by providing antioxidant defense. Moreover, it is well recognized that intracellular ROS generation is closely related to conserved apoptotic event, many chemotherapeutic drugs can induce generation of ROS and eventually result in death of the tumor cells. In this study, we showed that RTS treatment could significantly induce reduction of cell viability and upregulate apoptosis and DNA damage with abundant ROS accumulation. Not surprisingly, the level of intracellular ROS with RTS treatment was alleviated by additional NAC due to upregulation of GSH, and the cell viability, apoptosis and DNA damage in RTS group with additional NAC were not markedly changed compared with control (Fig. 3). Our recent studies indicated that the arsenic of RTS is absorbed into the cytoplasm, and inhibits the cellular antioxidant defense system, which lead to abundant ROS accumulation resulting in cell apoptosis.

Tumor suppressor protein p53 appears to have biphasic effects on cellular processes. Studies in vitro have shown that DNA damage induced by abundant accumulating cellular ROS could enhance p53 levels leading to cell cycle arrest and DNA repair. While the seriously damaged DNA is beyond the repaired capacity of p53, p53 is a nuclear protein that functions as a transcriptional activator, promoting expression of the 
pro-apoptotic gene Bax, and downregulating the expression of the antiapoptotic gene Bcl-2, and depriving mitochondrial membrane potential, and leading to cytochrome $c$ into the cytosol from mitochondria, and triggering the mitochondrial pathway of apoptosis $(1,15)$. In this study, we also examined relevance and association of the mitochondrial apoptosis pathway mediated by 553 in RTS-induced ROS production. Recent data from several studies show that RTS treatment could induce enhancement of the p53 mRNA and protein levels, and upregulation of the Bax protein levels, and the downregulation of the Bcl-2 protein levels (Fig. 2C and D). In addition, our study found that mitochondrial membrane potential was deprived due to the open permeability transition pore induced by the reducing rate of $\mathrm{Bcl}-2 / \mathrm{Bax}$, which led to the increasing cytochrome $c$ in cytosol (Fig. 4). It also can be reported that the formation of ROS in mitochondria could affect mitochondrial membrane potential, and promote cytochrome $c$ into cytosol (1). Consequently, we put forward that the mitochondrial membrane potential in RTS treatment group is closely related to cooperative action between the reducing rate of $\mathrm{Bcl}-2 / \mathrm{Bax}$ mediated by $\mathrm{p} 53$ and the direct interference of ROS to mitochondria.

Apoptosis dependent on cytoplasmic cytochrome $c$ is typically accompanied by the activation of caspase-3, which is a crucial downstream component of the apoptotic machinery and contributes to a wide range of morphological changes associated with apoptosis (15). Inactive pro-caspase-3 in cytoplasm is formed from a $35-\mathrm{kDa}$ zymogen under normal circumstances. While receiving stimulation of apoptosis signal, pro-caspase-3 is cleaved into $17 \mathrm{kDa}$ subunits, which generates activated cleaved-caspase-3 (34). In this study, we demonstrated that RTS treatment could induce decreasing procaspase-3 levels and increase the cleaved-caspase-3 (Fig. 2C). It was also observed that caspase- 3 activity in RTS treatment groups were significantly enhanced (Fig. 2E). These findings suggest that apoptosis induced by RTS is initiated through activated caspase-3.

Although p53 plays key roles in various cellular processes, the functions of p53 and p53 downstream signaling pathways in the cellular processes of proliferation remain to be clarified (35). Recent evidence suggests that a high level of p53 protein expression could induce the interruption of $\mathrm{G} 2 / \mathrm{M}$ progression to repair damaged DNA by inhibiting GADD45A protein expression. Gadd45A is a p53-effector and stress-inducible gene and is also able to associate with proteins involved in cell cycle regulation, such as $\mathrm{Cdc} 2 /$ cyclin $\mathrm{B}$, a key kinase for $\mathrm{G} 2 / \mathrm{M}$ progression. Additionally, Gadd45A binds to core histones in damaged DNA (11). In our study, we showed that RTS treatment could significantly interrupt G2/M phase in a time-dependent manner (Fig. 5A), and induce increasing Gadd45A protein levels and decreasing Cdc2/cyclin B protein levels (Fig. 5B). These results demonstrate that interruption of $\mathrm{G} 2 / \mathrm{M}$ progression induced by RTS is initiated through activated Gadd45A/Cdc2/cyclin B pathway.

In conclusion, we have established an effective biotransformation of realgar method by A.ferrooxidans, in which realgar was biologically converted into an aqueous solution, and have provided evidence that RTS has a strong activity inducing apoptosis and interrupting $\mathrm{G} 2 / \mathrm{M}$ progression in human hepatocellular carcinoma HepG2 cells via upregulation of cellular ROS. Importantly, our findings suggest a novel anticancer mechanism of RTS shown schematically in Fig. 5C. The ionic character of RTS allows it to easily penetrate the cell membrane and accumulate within cells. As an aqueous solution mainly containing arsenic and ferric ion, RTS could directly inhibit the activities of reductases and peroxidases leading to destruction of cellular redox status and abundant ROS accumulation. Furthermore, DNA damage induced by abundant accumulating of cellular ROS could enhance p53 expression levels leading to cell cycle arrest through activated Gadd45A/Cdc2/cyclin B pathway and apoptosis through activated mitochondrial pathway of apoptosis mediated by p53. Our data support a potential therapeutic use of pharmacological intervention in ROS signaling pathway for treating human hepatocellular carcinoma. However, future research such as improving biotransformation of realgar and observing anticancer potential of RTS in vivo is still needed for further elucidation.

\section{Acknowledgements}

This study was supported by the Gansu Province Science Foundation for Distinguished Young Scholars (grant no. 1308RJDA014); the Ministry of Science and Technology new drug project of MOST of China (2015ZX09501-004-003-008); the National Natural Science Foundation of China (81403145, 31571989, 31560176, 81560715, 31660026, 51501080); the Fundamental Research Funds for the Central Universities of China (Izujbky-2015-54, Izujbky-2016-152, Izujbky-2016-150); and the Technology Program of Lanzhou City (grant no. 2015-3-142).

\section{References}

1. Liu B, Chen Y and St Clair DK: ROS and p53: A versatile partnership. Free Radic Biol Med 44: 1529-1535, 2008.

2. Piskounova E, Agathocleous M, Murphy MM, Hu Z HuddlestunSE,ZhaoZ,Leitch AM,Johnson TM,DeBerardinis RJ and Morrison SJ: Oxidative stress inhibits distant metastasis by human melanoma cells. Nature 527: 186-191, 2015.

3. Duan D, Zhang B, Yao J, Liu Y and Fang J: Shikonin targets cytosolic thioredoxin reductase to induce ROS-mediated apoptosis in human promyelocytic leukemia HL-60 cells. Free Radic Biol Med 70: 182-193, 2014

4. Trachootham D, Alexandre J and Huang P: Targeting cancer cells by ROS-mediated mechanisms: A radical therapeutic approach? Nat Rev Drug Discov 8: 579-591, 2009.

5. Raj L, Ide T, Gurkar AU, Foley M, Schenone M, Li X, Tolliday NJ, Golub TR, Carr SA, Shamji AF, et al: Corrigendum: Selective killing of cancer cells by a small molecule targeting the stress response to ROS. Nature 526: 596, 2015.

6. Liu G and Chen X: Regulation of the p53 transcriptional activity. J Cell Biochem 97: 448-458, 2006.

7. Lim YP, Lim TT, Chan YL, Song AC, Yeo BH, Vojtesek B, Coomber D, Rajagopal G and Lane D: The p53 knowledgebase: An integrated information resource for p53 research. Oncogene 26: 1517-1521, 2007.

8. Donehower LA: Phosphatases reverse p53-mediated cell cycle checkpoints. Proc Natl Acad Sci USA 111: 7172-7173, 2014

9. Wulf GM, Liou YC, Ryo A, Lee SW and Lu KP: Role of Pin1 in the regulation of p53 stability and p21 transactivation, and cell cycle checkpoints in response to DNA damage. J Biol Chem 277: 47976-47979, 2002.

10. Lv C, Sun W, Sun H, Wei S, Chen R, Wang B and Huang C: Asperolide A, a marine-derived tetranorditerpenoid, induces G2/M arrest in human NCI-H460 lung carcinoma cells, is mediated by p53-p21 stabilization and modulated by Ras/Raf/ MEK/ERK signaling pathway. Mar Drugs 11: 316-331, 2013. 
11. Wang XW, Zhan Q, Coursen JD, Khan MA, Kontny HU, Yu L, Hollander MC, O'Connor PM, Fornace AJ Jr and Harris CC: GADD45 induction of a G2/M cell cycle checkpoint. Proc Natl Acad Sci USA 96: 3706-3711, 1999.

12. Essmann F, Pohlmann S, Gillissen B, Daniel PT, SchulzeOsthoff K and Jänicke RU: Irradiation-induced translocation of p53 to mitochondria in the absence of apoptosis. J Biol Chem 280: 37169-37177, 2005.

13. Marchenko ND, Zaika A and Moll UM: Death signal-induced localization of p53 protein to mitochondria. A potential role in apoptotic signaling. J Biol Chem 275: 16202-16212, 2000.

14. Zhao Y, Chaiswing L, Velez JM, Batinic-Haberle I, Colburn NH, Oberley TD and St Clair DK: p53 translocation to mitochondria precedes its nuclear translocation and targets mitochondrial oxidative defense protein-manganese superoxide dismutase. Cancer Res 65: 3745-3750, 2005.

15. Fulda $S$ and Debatin KM: Modulation of apoptosis signaling for cancer therapy. Arch Immunol Ther Exp (Warsz) 54: 173-175, 2006.

16. Wang H, Liu Y, Wang X, Liu D, Sun Z, Wang C, Jin G, Zhang B and Yu S: Randomized clinical control study of locoregional therapy combined with arsenic trioxide for the treatment of hepatocellular carcinoma. Cancer 121: 2917-2925, 2015.

17. Chen P, Yan L, Leng F, Nan W, Yue X, Zheng Y, Feng N and $\mathrm{Li} \mathrm{H}$ : Bioleaching of realgar by Acidithiobacillus ferrooxidans using ferrous iron and elemental sulfur as the sole and mixed energy sources. Bioresour Technol 102: 3260-3267, 2011.

18. Wang X, Zhang X, Xu Z, Wang Z, Yue X and Li H: Reversal effect of arsenic sensitivity in human leukemia cell line K562 and K562/ADM using realgar transforming solution. Biol Pharm Bull 36: 641-648, 2013.

19. Jiang H, Ding JH, Zhang YH, Shi ST, Gao S, Gong HZ and Sun GF: Study on water processing conditions of Realgar. Zhong Yao Cai 32: 26-28, 2009 (In Chinese).

20. Yan L, Yin H, Zhang S, Leng F, Nan W and Li H: Biosorption of inorganic and organic arsenic from aqueous solution by Acidithiobacillus ferrooxidans BY-3. J Hazard Mater 178: 209-217, 2010.

21. Xie QJ, Cao XL, Bai L, Wu ZR, Ma YP and Li HY: Anti-tumor effects and apoptosis induction by Realgar bioleaching solution in Sarcoma-180 cells in vitro and transplanted tumors in mice in vivo. Asian Pac J Cancer Prev 15: 2883-2888, 2014.

22. Zhang X, Xie QJ, Wang X, Wang B and Li HY: Biological extraction of realgar by Acidithiobacillus ferrooxidans and its in vitro and in vivo antitumor activities. Pharm Biol 48: 40-47, 2010.
23. Liu D, Zhi D, Zhou T, Yu Q, Wan F, Bai Y and Li H: Realgar bioleaching solution is a less toxic arsenic agent in suppressing the Ras/MAPK pathway in Caenorhabditis elegans. Environ Toxicol Pharmacol 35: 292-299, 2013.

24. Committee CP: Pharmacopoeia of the People's Republic of China. China Medical Science Press, Beijing, 2010.

25. Kuramata M, Sakakibara F, Kataoka R, Abe T, Asano M, Baba K, Takagi K and Ishikawa S: Arsenic biotransformation by Streptomyces sp. isolated from rice rhizosphere. Environ Microbiol 17: 1897-1909, 2015.

26. Kim JH, Kim HR, Lee BR, Choi ES, In SI and Kim E: Carcinogenic activity of $\mathrm{PbS}$ quantum dots screened using exosomal biomarkers secreted from HEK293 cells. Int J Nanomed 10: 5513-5527, 2015.

27. Chen SJ, Zhou GB, Zhang XW, Mao JH, de Thé H and Chen Z: From an old remedy to a magic bullet: Molecular mechanisms underlying the therapeutic effects of arsenic in fighting leukemia. Blood 117: 6425-6437, 2011.

28. Lau A, Whitman SA, Jaramillo MC and Zhang DD: Arsenicmediated activation of the Nrf2-Keap1 antioxidant pathway. J Biochem Mol Toxicol 27: 99-105, 2013.

29. Zhu J, Chen Z, Lallemand-Breitenbach V and de Thé H: How acute promyelocytic leukaemia revived arsenic. Nat Rev Cancer 2: 705-713, 2002

30. Kwong YL and Todd D: Delicious poison: Arsenic trioxide for the treatment of leukemia. Blood 89: 3487-3488, 1997.

31. He C, Jiang S, Jin H, Chen S, Lin G, Yao H, Wang X, Mi P, Ji Z, Lin Y, et al: Mitochondrial electron transport chain identified as a novel molecular target of SPIO nanoparticles mediated cancerspecific cytotoxicity. Biomaterials 83: 102-114, 2016.

32. Sharma VK and Sohn M: Aquatic arsenic: Toxicity, speciation, transformations, and remediation. Environ Int 35: 743-759, 2009.

33. Aposhian HV and Aposhian MM: Arsenic toxicology: Five questions. Chem Res Toxicol 19: 1-15, 2006.

34. Roh JL, Ko JH, Moon SJ, Ryu CH, Choi JY and Koch WM: The p53-reactivating small-molecule RITA enhances cisplatininduced cytotoxicity and apoptosis in head and neck cancer. Cancer Lett 325: 35-41, 2012.

35. Giono LE and Manfredi JJ: The p53 tumor suppressor participates in multiple cell cycle checkpoints. J Cell Physiol 209: 13-20, 2006. 